\title{
Research on the Effects of International R\&D on Carbon Productivity in China: Empirical Study Based on Dynamic Panel
}

\author{
Dawei Gao", Haisong Nie ${ }^{2 *}$, Marina Takeyasu²
}

${ }^{1}$ College of Economics and Management, Zhengzhou University of Light Industry, Henan 45003, China

2 Department of International Environmental and Agricultural Science, Tokyo University of Agriculture and Technology, 3-5-8 Saiwai-cho, Fuchu, Tokyo, 183-8509, Japan

*Corresponding author's e-mail: nie-hs@cc.tuat.ac.jp

How to Cite: Gao, D., Nie, H., Takeyasu, M. (2018). Research on the Effects of International R\&D on Carbon Productivity in China: Empirical Study Based on Dynamic Panel. Int. J. Agr. Syst. 6(2): 101-110

\begin{abstract}
At present, nearly $70 \%$ of the world's new increase carbon dioxide emission comes from China. Technology is the key power to develop low-carbon economy. Because of the shortage of independent $R \in \mathcal{E} D$ and the relative backwardness of low-carbon technology, Chinese need developed countries' $R \mathcal{E D}$ capital and advanced technology to promote low-carbon technologies. Based on the panel data from Chinese 30 provinces from 2001 to 2014 and dynamic panel model, this paper researchs on the effects of international RED on regional carbon productivity in China. The empirical results show that, the technology spillover effect of FDI and import trade can improve carbon productivity, and imported technology contracts play a positive role on carbon productivity, but not significant. There is a significant positive correlation between independent RED and carbon productivity. Finally, the corresponding policy is put forward according to the conclusions.
\end{abstract}

Copyright @ 2018 IJAS. All rights reserved.

Keywords:

International $R \&$ D; technology spillover; carbon productivity

\section{Introduction}

Global warming has caused worldwide attention. The increasing emission of Carbon Dioxide and other greenhouse gases has worsen global eco-environment. The government and academic circles are making efforts to explore the way to reduce the emission of greenhouse gases. In November, 2014, China and the US issued a joint communiqué on climate change in Beijing. For the first time, the US proposed that it would reduce the emission of greenhouse gases by $26 \%-28 \%$ by 2025 compared with 2005, refreshing its previous promise of reducing their emission of greenhouse gases by $17 \%$ by 2020 compared with 2005 . While China, for the first time, proposed that its carbon emission would peak by 2030 and that it would increase the rate of non-fossil energy by $20 \%$ among primary energies by 2030 . China, as a developing country, has surpassed the US and has become the world's largest carbon emission country since 2008. China is facing pressure from the promise of carbon emission reduction to the 
world and from deteriorative domestic living environment. Technological development is a key factor to realize the goal of carbon emission reduction and a core drive to develop low-carbon economy. Whereas, technological development depends on domestic independent R\&D and imported technologies. Because of the locking of core technologies by developed countries, China has to rely on international $\mathrm{R} \& \mathrm{D}$ capital technology spillover to promote its technology development. There is great significance for the research on the effects of international R \& D capital technology spillover on Chinese carbon productivity: on the one hand, the theory of energy economics can be enriched and improved; on the other hand, related international $R \& D$ introduction policy can be made to develop Chinese low-carbon economy, which can serve as reference for the carbon emission reduction of China.

Currently, there are many literatures on the effect of FDI and import trade technology spillover on carbon emission, but most of which study the two variables: value of imports and volume of direct investment from foreign business. Li Z H and Liu H H ${ }^{[1]}$ analyze the effect of different FDI channels on carbon emission using the penal data of 35 industrial sectors in China. Niu $\mathrm{H} \mathrm{X}$ and $\mathrm{Hu} \mathrm{J} \mathrm{Y}{ }^{[2]}$ research the effect of FDI on Chinese carbon emission by analyzing the ratio of FDI among the volume of investment in fixed assets. Liu $\mathrm{H} \mathrm{J}$ and Yan $\mathrm{Q} \mathrm{Y}^{[3]}$ study the effect of foreign trade and FDI on Chinese carbon dioxide emission by analyzing the time and penal data in China and the two variables, the ratio of total volume of imports and exports among GDP and the ratio of FDI volume among GDP, and conclude that FDI has negative effect on carbon dioxide emission. Yao $\mathrm{Y}$ and $\mathrm{Ni} \mathrm{Q}^{[4]}$ analyze the effect of direct investment and independent $R \& D$ by foreign enterprises from Chinese provinces and cities by use of inter-provincial panel data and make a conclusion that FDI and independent R\&D can effectively reduce the carbon intensity of many regions in China. Song D Yand Yi Y C[5] study the effect of FDI technology spillover on carbon dioxide emission by analyzing the ratio of FDI among GDP. Li K and Qi S Z[6] research the relationship between trade opening and carbon dioxide by use of inter-provincial penal data and conclude that trade opening increases the carbon dioxide emission and carbon intensity of Chinese provinces. Cheng Z, Bingnan $G$ and Jianke $\mathrm{W}^{[7]}$ adopt SFA model to analyze capital, labor and carbon dioxide and the research results show that FDI brings evident technology spillover effect to China. Guo Q B and Liu J ${ }^{[8]}$ study the effect of import trade technology spillover on carbon emission by analyzing the penal data of 29 provinces and cities of China. Deng Y [9] analyzes the effect of FDI and import trade technology spillover on Chinese carbon intensity by use of inter-provincial penal data model and concludes that FDI and import trade technology spillover can help cut carbon intensity. Liu C J and $\mathrm{Hu} \mathrm{W}{ }^{[10]}$ conduct studies and find that FDI has two totally different effects of "Pollution Heaven" and "Pollution Halo" on carbon productivity.

To conclude, import trade and FDI are main ways of international technology spillover, which can effectively reduce carbon intensity and carbon dioxide emission. According to current research literature, most focus on the effect of FDI and import trade volume on carbon emission, while there are few researches on the effect of technology spillover on carbon emission. Even if several studies focus on the effect of technology spillover on carbon intensity and carbon emission, they just study from the perspective of one or two technology spillover channels for FDI and import trade. This paper studies the effect of different technology spillover channels of international R\&D capital on regional carbon productivity of China by use of dynamic penal GMM estimation method and inter-provincial penal data, hoping to analyze and compare the 
effect of those technology spillover channels of international R\&D capital on regional carbon productivity of China and form an introduction strategy of international R\&D capital for all regions in China and also provide new insights into the development of Chinese low carbon economy and the realization of the carbon emission reduction promise to the world.

\section{Method}

\subsection{Formula capital stock}

Formulas of Lichtenberg F R et al. [11] are referred to for the setting of stock of foreign R\&D capital in all regions of China through the three spillover channels of FDI, import trade and foreign technical contracts, that is:

$$
\begin{aligned}
& S_{i t}^{p i}=\frac{I M_{i t}}{\sum_{i} I M_{i t}} \sum_{j=1}^{7} \frac{I M_{j t}}{Y_{j t}} S_{j t} \\
& S_{i t}^{p f}=\frac{F D I_{i t}}{\sum_{i} F D I_{i t}} \sum_{j=1}^{7} \frac{F D I_{j t}}{Y_{j t}} S_{j t} \\
& S_{i t}^{p c}=\frac{C O N_{i t}}{\sum_{i} C O N_{i t}} \sum_{j=1}^{7} \frac{C O N_{j t}}{Y_{j t}} S_{j t}
\end{aligned}
$$

In the above formulas, $S_{i t}^{p i} 、 S_{i t}^{p f}$ and $S_{i t}^{p c}$ refer to foreign R\&D capital in the region i of China through the three spillover channels of FDI, import trade and foreign technical contracts in the year $\mathrm{t}$; $I M_{j t}$ refers to the import volume of country $\mathrm{j}$ in the year $\mathrm{t}$; $F D I_{j t}$ refers to Chinese FDI volume of the country $\mathrm{j}$ in the year $\mathrm{t}$; $C O N_{j t}$ refers to the contract volume of technical introduction of the country $\mathrm{j}$ in the year $\mathrm{t} ; Y_{j t}$ refers to the GDP of the country j; $S_{j t}$ refers to the stock of R\&D capital of the country $\mathrm{j}$ in the year $\mathrm{t}$; $I M_{i t} 、 F D I_{i t}$ and $C O N_{i t}$ refer to the import trade volume, FDI volume and contract volume of foreign technical introduction in the region $\mathrm{i}$ in the year $\mathrm{t}$.

According to the formula of the capital stock, the R\&D capital stock $S_{j t}$ of G-7 countries (the US, Canada, Japan, France, Germany, Italy and the UK) can be calculated. According to the availability of data, the research time period of this paper is from 2001 to 2014. Firstly, historical GDP in fixed price (USD) in 2015 of G-7 countries are obtained from UNdata base; the ratio of R\&D expenditure among GDP for G7countries is obtained from OECD Factbook; the product of the historical GDP and the ratio of R\&D expenditure among GDP is R\&D expenditure. Secondly, the GDP and R\&D expenditure of G-7 countries are converted into RMB by the currency rate in 2005. The FDI data of 30 Chinese provinces and cities comes from "CEIC Chinese Economic Database"; import trade data of theses provinces comes from historical Statistical Yearbook of China; the data of imported technology contract volume comes from historical Science and Technology Statistical Yearbook of China. 


\subsection{Selection of variables and sources of data}

\subsubsection{Measurement of carbon productivity.}

This paper aims to research the effect of several technology spillover channels of international $R \& D$ capital by use of the dynamic penal data of 30 Chinese provinces and cities. Therefore, the dependent variable is set as carbon productivity $(\mathrm{CP})$ of 30 Chinese provinces and cities. Carbon productivity is calculated by the ratio between GDP and carbon dioxide emission of the same period. Pan J H(2010) ${ }^{[12]}$ considers that carbon productivity pursues the maximum production with the minimum carbon resources under a certain technical level. The future competition is not about labor productivity or the efficiency of oil, but carbon productivity.

This paper adopts a measurement method which Zha D L and Zhou D Q[13] uses to measure carbon emission of Chinese provinces. Final energy consumption is divided into 9 classes (coal, gasoline, diesel, natural gas, diesel, fuel oil, crude oil, electric power and coke) in Energy Statistical Yearbook of China; in this paper, the emission coefficient of the 8 kinds of fossil fuel except for electric power refers to the IPCC2006 version. Thermal power is a main source of carbon dioxide emission in the power industry. The total amount of carbon dioxide emission is calculated by the product of the investment amount of all kinds of energy in thermal power index of Chinese energy balance sheet and the sum of carbon dioxide coefficient; the annual emission coefficient of electric power department shall be the quotient of the total amount of carbon dioxide emission and the total amount of energy consumption. And the total amount of carbon dioxide emission of these provinces and cities is calculated by the sum amount of carbon dioxide from the above mentioned 9 fuels. Finally, divide the historical total amount of carbon emission of the provinces and cities by the GDP in the fixed price of 2005, the historical carbon productivity of these provinces and cities can be obtained. Related data is referred to historical Energy Statistical Yearbook of China.

\subsubsection{Domestic RED intensity in various regions}

As for domestic R\&D intensity, different scholars adopt different measurement indexes when conducting research. Jiao J L et al.[14] and Sun Y T et al.[15] use the ratio of R\&D expenditure among GDP to represent R\&D intensity. Based on this, this paper uses the ratio of internal R\&D expenditure among GDP to represent R\&D intensity. The data comes from historical Science and Technology Statistical Yearbook of China.

\subsubsection{Control variable}

On the basis of considering main factors that affect carbon dioxide, the following control variables are selected: Residents' consumption level. Residents' consumption level represents the economic development level of a nation or region. With the development of national economy, residents' consumption level is also rising and their consumption structure is also changing, accompanying the rising of energy consumption and carbon emission. Hence residents' consumption may cause remarkable influence on carbon productivity. The data of residents' consumption level comes from MacroChina Database and are converted into corresponding fixed price of 2005 by the consumer price index for the purpose of this paper. Industrial structure (IS). The change of industrial structure has significant influence on Chines carbon productivity. In this paper, the industrial structure is reflected by the ratio of the added value of the tertiary industry among GDP. Related data is referred to the official website of National Statistics Bureau. Financial interrelation ratio (FIR): The degree of 
financial development is reflected by financial interrelation ratio. The bigger of the value, the faster growth for the scale of financial activities and the higher degree of financial development. Financial interrelation ratio $(F I R)=$ the sum of loans and deposits balance of the financial institutions of a province/GDP of the current year of a province. The above data comes from Financial Statistical Yearbook of China. Population Size (PS). Population increase has a constant and long-lasting effect on greenhouse gas emission, especially carbon dioxide emission. The population is calculated by the number of people of all provinces and cities by the end of a year. The data comes from the Statistical Yearbook of China.

Table 1. Statistical description of variables

\begin{tabular}{lccccc}
\hline \multicolumn{1}{c}{ Variable } & Unit & $\begin{array}{c}\text { Max } \\
\text { value }\end{array}$ & $\begin{array}{c}\text { Average } \\
\text { value }\end{array}$ & $\begin{array}{c}\text { Min } \\
\text { value }\end{array}$ & $\begin{array}{c}\text { Standard } \\
\text { deviation }\end{array}$ \\
\hline LnCP (carbon productivity) & $\begin{array}{c}\text { 10 thousand yuan/ } \\
\text { ton }\end{array}$ & -0.31 & -1.61 & -3.14 & 0.56 \\
R\&D (domestic R\&D intensity) & $\%$ & 5.99 & 1.23 & 0.15 & 1.01 \\
LnPC (imported technical & 100 million yuan & 6.20 & 5.92 & -0.05 & 1.87 \\
contract) & 100 million yuan & 9.21 & 6.20 & 2.07 & 6.20 \\
lnPF (FDI) & 100 million yuan & 13.19 & 8.92 & 4.54 & 1.72 \\
lnPI (import trade) & $\%$ & 77.95 & 41.08 & 28.30 & 7.80 \\
IS (industrial structure) & $\%$ & 4.79 & 0.92 & 0.06 & 0.37 \\
lnFIR (financial interrelation ratio) & \% thousand persons & 9.28 & 8.14 & 6.26 & 0.75 \\
$\begin{array}{l}\text { lnPS (population size) } \\
\text { lnCL (residents' consumption }\end{array}$ & Yuan & 10.42 & 8.82 & 7.69 & 0.57 \\
level) & & &
\end{tabular}

\section{Results and Discussion}

This paper adopts the dynamic penal GMM estimation method to study the effect of international R\&D capital technology spillover on China's carbon productivity, mainly because the GMM estimation method can help overcome the problem of endogeneity in the model. The GMM estimation method contains first-order difference GMM and first-order system GMM. Because in most cases, the lagged value of variables is not an ideal instrumental variable for first-order difference equation, the system GMM estimation method is more effective, which can use both one-step estimation method and two-step estimation method. A key assumption of GMM method is that there is no serial correlation for the disturbance term in the model. If there is only first-order selfcorrelation without second-order self-correlation for the differenced disturbance term, the assumption can be determined to be reasonable. The empirical results in this paper show the statistics of AR(2). Meanwhile, in order to detect the validity of instrumental variables, this paper also shows the Sargan statistics used to detect over-identified constraint. Coe D T and Helpman $\mathrm{E}^{[16]}$ proposed classical international R\&D capital technology spillover model. A dynamic penal model on the effect of international R\&D capital technology spillover on China's carbon productivity:

$$
L n C P_{i t}=\alpha+\beta_{1} L n C P_{i t-1}+\beta_{2} L n S_{i t}^{d}+\beta_{3} L n S_{i t}^{p f}+\beta_{4} L n S_{i t}^{p i}+\beta_{5} \operatorname{Ln} S_{i t}^{p c}+\sum \beta_{j} X_{j i t}+\varepsilon_{i t}
$$




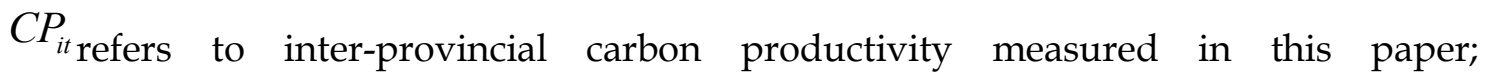
$S_{i t}^{d}$ represents the technical progress of domestic R\&D capital; $S_{i t}^{p f}$, $S_{i t}^{p i}$ and $S_{i t}^{p c}$ respectively represents international R\&D capital stock obtained through three technology spillover channels of FDI, import trade and imported technology contract. $X_{j i t}$ refers to a set of control variables, indicating other factors which affect carbon productivity except for the factor of international R\&D capital.

Before studying the effect of international $R \& D$ capital technology spillover on carbon productivity by use of dynamic penal data, the inflation factors of independent variables shall be calculated. The table 2 shows that the inflation factors of independent variables are less than 10, which can be deemed as no strong linear problems among variables.

Table 2. Inflation factors of variables

\begin{tabular}{ccc}
\hline Variable & VIF & 1/VIF \\
\hline $\operatorname{lnPI}$ & 6.50 & 0.153841 \\
$\operatorname{lnCL}$ & 2.95 & 0.338426 \\
R\&D & 3.91 & 0.255549 \\
$\operatorname{lnPC}$ & 3.09 & 0.323729 \\
$\operatorname{lnPF}$ & 3.69 & 0.271071 \\
IS & 3.65 & 0.273864 \\
$\operatorname{lnPS}$ & 2.28 & 0.438629 \\
$\ln F I R$ & 1.78 & 0.562573 \\
\hline
\end{tabular}

Table 3 shows the system GMM empirical results and the difference GMM empirical results respectively and their measurement results are as follows. According to Table 3, Wald test values about the joint significance of model coefficient are obvious on $1 \%$ level; the test results of second order sequence correlation (AR (2)) show that there is no second-order sequence self-correlation in residual after the first-order difference, which indicates that the model built in this paper is reasonable; the results of Sargan over-identification test also shows that the instrumental variables used in regression are appropriate (the $\mathrm{p}$ value in the second and fourth line are above 0.1). Meanwhile, the variables of two-step system GMM pass the $10 \%$ significance test and theoretically, the standard covariance matrix of the two-step estimation method is always robust[17], so the results of the two-step system GMM estimation are adopted to conduct the analysis.

Table 3. Results of Empirical Analysis.

\begin{tabular}{|c|c|c|c|c|}
\hline $\begin{array}{l}\text { Dependent } \\
\text { variable }\end{array}$ & $\operatorname{lnCP}$ & & & \\
\hline $\begin{array}{l}\text { Independent } \\
\text { variable }\end{array}$ & $\begin{array}{ll}\begin{array}{l}\text { System } \\
\text { (one- step) }\end{array} & \text { GMM }\end{array}$ & $\begin{array}{ll}\begin{array}{l}\text { System } \\
\text { (two- step) }\end{array} & \text { GMM }\end{array}$ & $\begin{array}{ll}\begin{array}{l}\text { Difference } \\
\text { (one- step) }\end{array} & \end{array}$ & $\begin{array}{ll}\begin{array}{l}\text { Difference } \\
\text { (two- step) }\end{array} & \text { GMM }\end{array}$ \\
\hline $\ln C P(t-1)$ & $\begin{array}{l}0.7663^{* * *} \\
(0.0303)\end{array}$ & $\begin{array}{l}0.7708^{* * *} \\
(0.0331)\end{array}$ & $\begin{array}{l}0.6799 * * * \\
(0.0421)\end{array}$ & $\begin{array}{l}0.6814^{* * *} \\
(0.0340)\end{array}$ \\
\hline $\ln P F$ & $\begin{array}{l}0.0242^{* *} \\
(0.0105)\end{array}$ & $\begin{array}{l}0.0209^{* * *} \\
(0.0045)\end{array}$ & $\begin{array}{l}0.0113 \\
(0.0105)\end{array}$ & $\begin{array}{l}0.0088 \\
(0.0055)\end{array}$ \\
\hline R\&D & $\begin{array}{l}0.0174 \\
(0.0215)\end{array}$ & $\begin{array}{l}0.0199^{*} \\
(0.0108)\end{array}$ & $\begin{array}{l}-0.0433 \\
(0.0328)\end{array}$ & $\begin{array}{r}-0.0356^{*} \\
(0.0197)\end{array}$ \\
\hline $\ln P I$ & $\begin{array}{l}0.0748^{* * *} \\
(0.0148)\end{array}$ & $\begin{array}{l}0.0738^{* * *} \\
(0.0092)\end{array}$ & $\begin{array}{l}0.0373^{* *} \\
(0.0179)\end{array}$ & $\begin{array}{l}0.0353^{* * *} \\
(0.0077)\end{array}$ \\
\hline
\end{tabular}




\begin{tabular}{|c|c|c|c|c|}
\hline $\ln P C$ & $\begin{array}{l}0.0022 \\
(0.0042)\end{array}$ & $\begin{array}{l}0.0026 \\
(0.0017)\end{array}$ & $\begin{array}{c}-0.0002 \\
(0.0042)\end{array}$ & $\begin{array}{c}-0.0005 \\
(0.0013)\end{array}$ \\
\hline IS & $\begin{array}{l}0.0085^{* * *} \\
(0.0018)\end{array}$ & $\begin{array}{c}0.0084^{* * *} \\
(0.0009)\end{array}$ & $\begin{array}{l}0.0073^{* * *} \\
(0.0019)\end{array}$ & $\begin{array}{l}0.0067^{* * *} \\
(0.0009)\end{array}$ \\
\hline $\ln P S$ & $\begin{array}{l}-0.0759^{* * *} \\
(0.0266)\end{array}$ & $\begin{array}{l}-0.0753^{* *} \\
(0.0328)\end{array}$ & $\begin{array}{l}-0.1527 \\
(0.0019)\end{array}$ & $\begin{array}{r}-0.0143 \\
(0.3727)\end{array}$ \\
\hline $\operatorname{lnCL}$ & $\begin{array}{l}-0.1287^{* * *} \\
(0.0298)\end{array}$ & $\begin{array}{l}-0.1252^{* * *} \\
(0.0176)\end{array}$ & $\begin{array}{l}-0.0998^{* * *} \\
(0.0330)\end{array}$ & $\begin{array}{l}-0.1053^{* * *} \\
(0.0286)\end{array}$ \\
\hline $\operatorname{lnFIR}$ & $\begin{array}{l}-0.1239 \\
(0.0174)\end{array}$ & $\begin{array}{c}-0.0115 \\
(0.0086)\end{array}$ & $\begin{array}{l}-0.0065 \\
(0.0170)\end{array}$ & $\begin{array}{c}-0.0037 \\
(0.0060)\end{array}$ \\
\hline Constant term & $\begin{array}{l}0.1404 \\
(0.2813)\end{array}$ & $\begin{array}{l}0.1417^{* * *} \\
(0.2617)\end{array}$ & $\begin{array}{l}0.9273^{* * *} \\
(1.2304)\end{array}$ & $\begin{array}{l}-0.0933^{* * *} \\
(2.83)\end{array}$ \\
\hline $\begin{array}{l}\text { Number } \\
\text { samples }\end{array}$ & 390 & 390 & 360 & 360 \\
\hline Wald Test & $7289.32^{* * *}$ & $52724.70^{* * *}$ & $3553.85^{* * *}$ & $23290.36^{* * *}$ \\
\hline $\mathrm{AR}(2) \operatorname{test}(\mathrm{P})^{(1)}$ & - & 0.1997 & - & 0.2084 \\
\hline Sargan test(p) (2) & 0.0000 & 1.0000 & 0.0000 & 1.0000 \\
\hline
\end{tabular}

(1) Seen from the aspect of technology spillover effect of FDI, technology spillover effect of FDI can effectively enhance China's carbon productivity. Technology spillover effect of FDI can promote technical progress and the growth of productivity of a country mainly by means of demonstration, competition, correlation and personnel turnover. Foreign owned enterprises own advanced low-carbon technology and constant R\&D investment ability and more efficient energy utilization technology and low-carbon technology than domestic enterprises. These advanced technologies can function as a model, so they can be followed and absorbed. Meanwhile, domestic enterprises are facing the challenge brought by products with competitive advantages from foreign owned enterprises. Under the competitive pressure, domestic enterprises will make use of advanced technology with more competitiveness, so as to enhance the carbon productivity of domestic enterprises. Besides, the personnel turnover between foreign owned enterprises and domestic enterprises will improve the low-carbon technical level of domestic enterprises. Therefore, by making full use of the technology spillover effect of FDI, China can obtain advanced low-carbon technology of developed countries, thus the carbon productivity is wholly enhanced and the emission of carbon dioxide is reduced.

(2) Domestic independent R\&D has positive correlation with carbon productivity, which indicates that the enhancement of China's independent R\&D level can help raise carbon productivity. Low-carbon independent $R \& D$ is a critical way and source for the growth of China's low-carbon technology. Independent R\&D can not only improve China's innovative ability and technical level, but also help promote the digestion and absorption of advanced low-carbon technologies from foreign countries and reduce the gap between domestic and foreign technologies. Domestic independent R\&D can not only directly raise China's low-carbon technical level, but also absorb and digest advanced technologies caused by the technology spillover effect of international R\&D capital, so as to raise China's carbon productivity.

(3) Seen from the perspective of import trade technology spillover effect, international R\&D capital can help raise carbon productivity through the channel of import trade. According to the coefficients of independent variables, import trade plays the biggest role among all technology spillover channels. The technology spillover effect of import trade improve the low-carbon technology level of Chinese provinces and cities by 
absorbing the energy saving and emission reduction technology materialized in import intermediate and capital goods. China imports capital goods and intermediate goods with higher technical content and imitates the advanced technology materialized in these import goods. Thus, the technology spillover effect of import trade channel in international R\&D capital by applying these technologies to production.

(4) Imported technology contracts have a weak positive correlation with carbon productivity, that is to say, imported technology contracts can help exert the technology spillover effect to a certain degree and raise China's regional carbon productivity. The main reason may be that the technology spillover of technical contract channel belongs to a kind of direct technology, where direct introduction of foreign advanced technology helps develop China's technology level. But there is only small transaction amount of imported technology contracts in Chinese provinces and cities, especially in central and western regions and low foreign technology spillover effect can be obtained. Thus the effect of the channel of imported technology contracts on carbon productivity is not that obvious.

(5) In view of control variables, residents' consumption level has a remarkable negative correlation with carbon productivity. With the fast development of Chinese economy, residents' consumption level also improves a lot. Especially after the year 2000, China's residents' consumption enters the modern consumption stage and residents' consumption begins to focus more on carbonized products. Therefore, the rise of residents' consumption level helps reduce carbon productivity. Population size has a remarkable negative correlation with carbon productivity, which indicates that, with the increasing number of population, more fossil energy are needed to satisfy the demands for larger and larger population and their survival. The development level of the tertiary industry has a remarkable positive correlation with carbon productivity. At present, the proportion of the tertiary industry in the whole national economy keeps increasing. Compared with the secondary industry, the tertiary industry may consume less fossil energy and thus the emission of carbon dioxide may be reduced largely. So, developing the secondary industry can help effectively reduce the emission of carbon dioxide. The expanding scale of financial activities can help reduce carbon productivity. The main reason is that new energy enterprises and energy conservation and emission reduction enterprises belong to enterprises which have higher risk and slower recovery of the capital and that technical uncertainty and higher risk make financial institutions invest more capital into other enterprises.

\section{Conclusion}

FDI and import trade technology spillover effect can efficiently enhance Chinese carbon productivity; imported technology contracts have a noticeable negative correlation with carbon productivity and domestic independent R\&D presents a remarkable positive correlation with carbon productivity; seen from control variables, residents' consumption level follow the same trends as carbon productivity; the ratio of coal consumption among energy consumption shows a significant negative correlation with carbon productivity and the development level of the tertiary industry has a weak positive correlation with carbon productivity. FDI and import trade technology spillover are main ways for the improvement of technical level of a country. FDI can play its technology spillover effect to enhance Chinese low-carbon technical level by means of demonstration, competition effect and human resource flow between domestic and foreign owned enterprises. China should further adjust the FDI policy, 
introduce foreign direct investment with higher energy utilization ability and lowcarbon technology. Domestic enterprises should continue to strengthen their communication with foreign owned enterprises and obtain advanced low-carbon technology by relying on personnel training, visiting and learning and other ways. Chinese government should create more transparent environment of fair competition and attract more foreign owned enterprises with advanced technology to enter Chinese market. With respect to import trade, China should continue to optimize the import structure of intermediate and capital goods, give full play to the technology spillover effect through import trade channel. Import tariff structure should be adjusted and optimized; domestic enterprises shall be encouraged to introduce more foreign advanced technology and key production equipment. With respect to the introduction contracts of foreign technology, compared with FDI and import trade, their contract amount are relatively small; the introduction contracts of foreign technology bring little positive effect, though they exert the technology spillover effects of foreign advanced technology to a certain degree. Therefore, more contracts of advanced low-carbon technology should be efficiently signed. With respect to independent research and development, China should issue corresponding incentive policies to enhance enterprises' initiative in independent R\&D. Especially in energy utilization technology and low-carbon technology, the government shall give policy support, so that enterprises can make full use of their innovation and abilities and a regional lowcarbon technology innovation system centered on enterprises can be gradually established.

\section{Acknowledgments}

We acknowledge the financial support from the National Natural Science Foundation of China (No.1404707), the Natural Science Foundation of Henan Province (No.182300410158).

\section{References}

[1] Li Z H and Liu H H 2011Technical Effect of FDI on Carbon Emission China Population, Resources and Environment 21 27-33

[2] Niu H X and Hu J Y 2011Empirical Research on Relationship Between FDI and CO2 Emission in China International Trade Issues 5 100-9

[3] Liu H J and Yan Q Y 2011 Trade Openness, FDI and China's Carbon Dioxide Emissions The Journal of Quantitative \& Technical Economics 3 21-35

[4] Yao Y and Ni Q 2011FDI, Independent R\&D and Carbon Intensity-Empirical Research Based on the Provincial Penal Data Soft Science 25 19-24

[5] Song D Y and Yi Y C 2011 FDI and China's Carbon Emissions China Population, Resources and Environment 21 49-52

[6] Li K and Qi S Z 2011Trade Openness, Economic Growth and Carbon Dioxide Emission in China Econmic Research 11 60-72

[7] Cheng Z,Bingnan G and Wang J K 2014 The different impacts of home countries characteristics in FDI on Chinese spillover effects: Based on one-stage SFA Economic Modelling 3 53-63 
[8] Guo Q B and Liu J P 2013Import Trade, Technology Spillover and China's Carbon's Emissions China Population, Resources and Environment 23 105-9

[9] Deng Y 2015 The Effect of Import Trade and FDI Technology Spillover on China's Carbon Intensity Statistics and Decision 3 156-158

[10] Liu C J and Hu W 2016 Has FDI improved China's Carbon Productivity? Experience Analysis Based on Space Penal Durbin Model World Economy Study 1 99-109

[11] Lichtenberg F R et al 1998 International R\&D Spillovers: A Re-examination European Economic Review 428 1483-91

[12] Pan J H 2010 How to Develop China's Low-carbon Economy China Market 11 6165

[13] Zha D L and Zhou D Q 2007 The Inequality about Provincial Energy Efficiency and Its Related CO2 Emission: Decomposition Based on Kaya System Engineering 25 65-71

[14] Jiao J L et al. 2017 Technology Spillover of Import Trade Regional Difference and Influencing Factors Journal of Beijing Institute of Technology (Social Sciences Edition) $156-63$

[15] Sun Y T et al 2015 Pattern Evolution and Effect on Portfolio of Indigenous R\&D Effort and International Technology Flow Studies in Science of Science 33 1151-60

[16] Coe D T and Helpman E 1995 International R\&D Spillovers European Economic Review 39 859-87

[17] Roodman D 2006 How to do Xtabond2: An introduction to "Difference" and "System" GMM in stata Center for Global Development Working Paper 9 86-136 